\title{
Pembuatan Sabun Cuci Tangan Dalam Peran Serta Penanganan Covid 19 Berdasarkan Peraturan Menteri Kesehatan Nomor 62 Tahun 2017 Bersama PCM Kramat Jati Dan Pemuda Muhammadiyah Kramat Jati Jakarta Timur - DKI Jakarta
}

\begin{abstract}
Marjan Miharja, Wiend Sakti Myharto, Valentino Brostito, Hasan, Muhammad Sofyan Hidayat, Yulius Alfredo, Emilio Raynaldi Porwayla \& Novariyadi Putra Ardhana
\end{abstract}

Sekolah Tinggi Ilmu Hukum "IBLAM"

\begin{abstract}
The spread of Covid-19 has become one of the people's concerns, starting in the city of Wuhan, China at the end of 2019 when this virus was discovered, the spread of the virus that the antidote has not yet been found is now out of control. More than 200 countries in the world have reported that their people have contracted the Covid-19 virus. Corona Virus Disease 19 has been declared a Global Public Health Emergency by the World Health Organization (WHO) on January 30, 2020. Conditions in Indonesia until Thursday, November 30, 2020, the number of people who tested positive for Covid-19 reached 538,883 cases, 450,518 people recovered and 16,945 of them died. This figure will continue to increase in line with the opinion of some epidemiologists and statistics that a pandemic outbreak will not end quickly. The purpose of this community service activity is to realize one of the contents of the Minister of Health Regulation No. 62 of 2017, namely "Distribution Permits for Medical Devices, In Vitro Diagnostic Medical Devices and Household Health Supplies", namely by making and distributing Hand Washing Soap that is safe, durable and as recommended by the BPOM and the World Health Organization (WHO) to help people face the New Normal era. The result of this service activity is hand soap that is safe and environmentally friendly and is able to anticipate the spread of covid-19 and increase public awareness of the Covid-19 Virus in the face of the New Normal era.
\end{abstract}

Keywords Hand soap, Covid-19, Jakarta

\section{Pendahuluan}

Pengabdian kepada masyarakat merupakan salah satu dari Tri Dharma Perguruan Tinggi, Pengabdian Kepada Masyarakat (PKM) termasuk mata kuliah lapangan yang menitik beratkan pada kerja dan sosialisasi mahasiswa / mahasiswi dimasyarakat. Mata kuliah PKM di STIH IBLAM Jakarta mempunyai sasaran pada masyarakat yang terkena wabah pandemi COVID-19.

Sesuai dengan jurusan dari Sekolah Tinggi yang kami tekuni sekarang, kami coba melihat kembali Aspek Hukum Penanganan Penyebaran Covid-19, yang mana Kesehatan adalah salah satu kebutuhan dasar manusia, yang belakangan telah dijamin haknya secara konstitusional. Melalui Perubahan Kedua Undang-Undang Dasar 1945, kesehatan ditegaskan sebagai bagian dari hak asasi manusia. Dalam Pasal $28 \mathrm{H}$ ayat (1) dinyatakan, bahwa: "Setiap orang berhak hidup sejahtera lahir dan batin, bertempat tinggal, dan mendapat lingkungan hidup yang baik dan sehat serta berhak memperoleh pelayanan kesehatan." Masuknya ketentuan tersebut ke dalam Undang-Undang Dasar 1945, menggambarkan perubahan paradigma yang luar biasa. Kesehatan dipandang tidak lagi

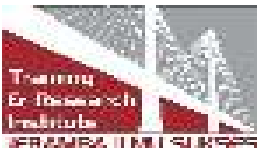


sekedar urusan pribadi yang terkait dengan nasib atau karunia Tuhan yang tidak ada hubungannya dengan tanggung jawab negara,melainkan suatu hak hukum (legal rights) yang tentunya dijamin oleh Negara.

New normal menjadi babak baru setelah pandemi Covid-19 dimana semua pola kehidupan berubah mengikuti aturan pemerintah dengan adanya sosial distancing, dan wajib penggunakan masker bahkan ada sanksi jika aturan baru ini tidak diterapkan, karena new normal merupakan tatanan kehidupan yang baru dan harus dipatuhi demi menekan penyebaran pandemi ini. Meskipun sudah memasuki kondisi new normal, wabah ini tetap harus diwaspadai karena wabah ini diperkirakan masih akan berlanjut jika tatanan baru yang ada tidak dipatuhi. Tatanan kehidupan baru atau kenormalan baru yang harus dijalani akan berakibat makin buruk jika kita tidak taat pada protokol kesehatan yang diisyaratkan pemerintah. Dalam menghadapi kondisi new normal, perilaku dan tindakan masyarakat harus berubah total dari tindakan biasa yang sering di lakukan. Sudah banyak himbauan dari pemerintah terkait perubahan prilaku yang harus dilakukan, namun nampaknya tidak mempengaruhi semua orang secara merata. Melihat kondisi ini, tidak menyurutkan semangat untuk melakukan kegiatan pengabdian kepada masyarakat. Tim Pengabdi Kepada Masyarakat (PKM) STIH IBLAM yang diketuai oleh Dr. Marjan Miharja S.H.,M.H. melakukan kegiatan ini dengan cara membuat dan mendistribusikan produk sabun cuci tangan untuk mewujudkan salah satu isi Peraturan Menteri Kesehatan Nomor 62 Tahun 2017 yaitu "Izin Edar Alat Kesehatan, Alat Kesehatan Diagnostik In Vitro dan Perbekalan Kesehatan Rumah Tangga". Dalam pembuatan produk tersebut kami Tim Pengabdi STIH IBLAM bekerjasama dengan Mitra PCM Kramat Jati dan PWPM DKI Jakarta.

Kegiatan pertama kami adalah melakukan observasi ketempat Pemuda Muhammadiyah DKI Jakarta dengan melihat kegiatan apa saa yang bisa kami jadikan sebagai bahan PKM yang berhubungan dengan regulasi pemerintah tentang penanganan bencana COVID-19, mulai dari apa yang akan kami hasilkan, tempat pelaksanaan PKM, menganalisa kondisi lingkungan tempat mitra kami, produk yang dihasilkan, bahan bahan yang dibutuhkan, dan lainnya. Setelah melakukan observasi dan diskusi dengan pihak PCM Kramat Jati dan PWPM DKI Jakarta beserta pembimbing maka diperoleh gambaran mengenai apa yang harus kami lakukan dan akan kami gunakan dalam menyusun program kerja dan target dalam MK PKM kami, dengan tetap sesuai rencana kami membantu pemerintah dalam regulasi penanganan wabah COVID-19.

Target kami dalam kegiatan PKM ini yaitu ingin membantu pemerintah dalam menurunkan menyebaran wabah pandemi, serta membantu pemerintah menumbuhkan rasa disiplin akan kebersihan diri dan lingkungan bagi masyarakat, karena kebersihan merupakan salah satu kunci untuk kita bisa melewati masa pandemi saat ini. Untuk mengembangkan usaha ini kami mengalokasikan dana mandiri kelompok kami. Adapun rumusan masalah adalah: (a) Bagaimana membuat sabun cuci tangan yang aman tahan lama serta ramah lingkungan yang direkomendasikan oleh BPOM dan Organisasi Kesehatan Dunia (WHO) untuk membantu masyarakat menghadapi era New Normal ? (b) Susahnya mendapatkan bahan dasar pembuatan sabun cuci tangan yang sesuai dengan kadar yang diperlukan; (c) Waktu, merupakan permasalahan kami dan mitra dalam proses pembuatan sabun cuci tangan ini.

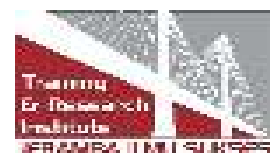




\section{Solusi Permasalahan}

Dengan permasalahan yang ada yaitu mengenai produksi pembuatan sabun cuci tangan dan mengenai waktu serta bahan bahan dasar yang susah kami apatkan, maka kami mencoba berkoordinasi dengan pihak Mitra 1 PWPM DKI Jakarta mengenai jadwal yang telah kami susun untuk kegiatan PKM ini, solusi yang kami dapatkan, sebagai berikut (a) Dengan Kepakaran yang dimiliki Mitra 1 PWPM DKI Jakarta, kami dapat membuat Sabun cuci tangan yang aman dan sesuai standar BPOM; (b) Berkoordinasi dengan Mitra kami PCM Kramat Jati dan PWPM DKI Jakarta Koordinasi yang dimaksud guna menyesuaikan dengan waktu yang mitra miliki agar semua jadwal dapat berjalan sesuai rencana dan kami juga dapat segera menyelesaikan tugas ini sesuai waktu yang telah ketua PKM berikan; (c) Dari beberapa solusi diatas ada target luaran yang akan kami lakukan yaitu dengan menginfokan pada masyarakat baik berupa Jurnal, video youtube maupun berita di media cetak maupun online, bahwa kami sebagai mahasiswa juga dapat memberikan sumbangsih kepada negara dan masyarakat Indonesia sesuai dengan kemampuan kami sebagai mahasiswa.

\section{Metode Pelaksanaan Kegiatan}

Metode pelaksanaan kami buat untuk mencapai tujuan dari Kegiatan Pengabdian Kepada Masyarakat dalam mengatasi masalah masyarakat untuk menghadapi kondisi new normal, yang kami lakukan sebagai Tim Pengabdian Kepada Masyarakat adalah dengan menyumbang Produk Sabun cuci tangan yang telah dibuat bersama mitra PWPM DKI Jakarta yang nantinya akan dibantu oleh mitra 2 kami yaitu PCM Kramat Jati untuk dibagikan kepada masyarakat sekitar mitra kami berdomisili.

Ada beberapa permasalahan yang menjadi kendala dalam kegiatan kami salah satunya adalah waktu, maka solusi yang kami hadirkan dalam pelaksanaan kegiatan ini ada beberapa metode, sebagai berikut :

Tabel 1. Metode Pelaksanaan Kegiatan

\begin{tabular}{|c|c|c|c|}
\hline NO. & PERMASALAHAN & $\begin{array}{c}\text { SOLUSI } \\
\text { PERMASALAHAN }\end{array}$ & $\begin{array}{c}\text { METODE } \\
\text { PELAKSANAAN }\end{array}$ \\
\hline 1. & $\begin{array}{l}\text { Cara membuat sabun cuci } \\
\text { tangan yang aman dan } \\
\text { sesuai standar BPOM. }\end{array}$ & $\begin{array}{l}\text { Dari permasalahan } \\
\text { yang ada kami mencoba } \\
\text { berkoordinasi dengan } \\
\text { mitra kami, dan kami } \\
\text { mendapatkan informasi } \\
\text { cara membuat sabun } \\
\text { cuci tangan yang aman } \\
\text { dan ramah lingkungan, } \\
\text { dengan bahan bahan } \\
\text { dan komposisi yang } \\
\text { sudah sesuai standar } \\
\text { kesehatan dan tidak ada } \\
\text { efek samping yang } \\
\text { dihasilkan. }\end{array}$ & $\begin{array}{l}\text { Dari bahan bahan } \\
\text { yang telah ada kami } \\
\text { melakukan } \\
\text { pencampuran bahan } \\
\text { tersebut dengan } \\
\text { komposisi } \\
\text { secukupnya sesuai } \\
\text { takaran dari sabun } \\
\text { cuci tangan yang } \\
\text { akan dibuat. }\end{array}$ \\
\hline 2. & Waktu dengan mitra yang & Waktu adalah masalah & Mencocokan jadwal \\
\hline
\end{tabular}

Published by:

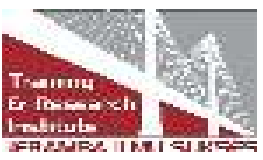




\begin{tabular}{|c|c|c|c|}
\hline & $\begin{array}{ll}\text { tidak sesuai sehingga perlu } \\
\text { dikoordinasikan } & \text { lebih } \\
\text { lanjut. } & \end{array}$ & $\begin{array}{lr}\text { yang sangat menjadi } \\
\text { penentu akan kegiatan } \\
\text { PKM ini, maka dari itu } \\
\text { koordinasi r dan } \\
\text { menyesuaikan waktu } \\
\text { dengan mitra adalah } \\
\text { jalan keluar dari } \\
\text { masalah ini agar semua } \\
\text { rencana tetap berjalan } \\
\text { dengan seharusnya. }\end{array}$ & $\begin{array}{lr}\begin{array}{l}\text { kegiatan } \\
\text { dengan } \\
\text { kosong atau }\end{array} \text { waktu } \\
\text { senggang mitra } \\
\text { PWPM DKI Jakarta, } \\
\text { sehingga akhirnya } \\
\text { program yang ada } \\
\text { dapat berjalan sesuai } \\
\text { rencana yang sudah } \\
\text { kami buat tanpa } \\
\text { harus mengurangi } \\
\text { jadwal dari PKM } \\
\text { yang sudah tersusun. }\end{array}$ \\
\hline 3. & $\begin{array}{l}\text { Mencari bahan - bahan } \\
\text { dasar dengan prosentasi } \\
\text { kandungan } \quad \text { sesuai } \\
\text { kebutuhan, sebagai berikut: } \\
\text { - Cocamidopropyl } \\
\text { Betaine } \\
\text { - Sodium Lauril } \\
\text { - Ether Sulfat } \\
\text { - Na-EDTA } \\
\text { - NaCL } \\
\text { - Sodium Sulfat } \\
\text { - Fragance } \\
\text { - Air Bersih }\end{array}$ & 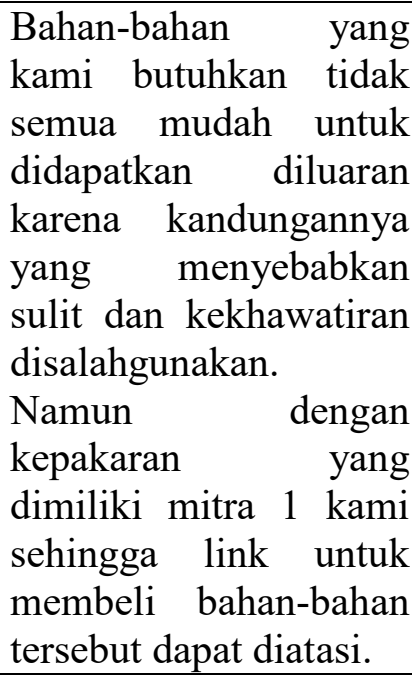 & $\begin{array}{lr}\text { Dengan link dari } \\
\text { mitra } 1 \text { kami PWPM } \\
\text { DKI Jakarta, bahan } \\
\text { bahan produki sabun } \\
\text { cuci tangan } \text { bisa } \\
\text { kami dapatkan } \\
\text { dengan kadar serta } \\
\text { kandungan sesuai } \\
\text { dengan r yang } \\
\text { diharapkan. }\end{array}$ \\
\hline
\end{tabular}

\section{Pelaksanaan Kegiatan}

Tahapan awal dari kegiatan ini adalah kami melakukan observasi ke pihak mitra dengan beberapa kegiatan hingga Tahapan Laporan Akhir, sebagai berikut :
a. Kunjungan ke PCM Kramat Jati dan PMW DKI Jakarta
b. Mendapatkan bimbingan dari PCM Kramat Jati dan PWPM DKI Jakarta tentang apa yang akan menjadi tema dalam PKM kami kali ini.
c. Mengajukan Proposal Kegiatan PKM di STIH Iblam Kramat Raya,Jakarta Pusat
d. Membuat Sabun cuci tangan adalah arahan dari mitra 1 PWPM DKI Jakarta.
e. Melakukan Baksos dilingkungan sekitar mitra berdomisili yang diwakili oleh Mitra 2 PCM Kramat Jati.
f. Laporan Harian bentuk pertanggungjawaban kepada ketua PKM.
g. Laporan Akhir Kegiatan di PCM Kramat Jati.

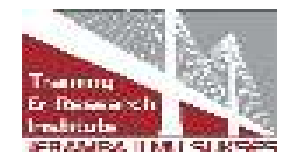


1. Masukan Ethanol 96\% secukupnya kedalam wadah ukuran 10 liter

2. Tambahkan Hydrogen Peroxide 3\% secukupnya

3. Masukan Glycerol 98\% secukupnya

4. Isi Wadah ukuran 10 liter dengan bahan yang sudah dicampur tadi dengan air matang dingin

5. Setelah terisi penuh tutup wadah sesegera mungkin untuk menghindari penguapan

6. Goyang kan wadah dengan perlahan agar bahan tercampur dengan rata

7. Simpan selama 72 jam untuk memastikan tidak ada kontaminasi organisme dari wadah botol

8. Hand Sanitizer siap digunakan

$>\quad$ Kegiatan Pertama / Kamis ,13 November 2020

Bimbingan PKM (Ketua PKM Dr. Marjan Miharja, S.H.,M.H.)

Pengarahan Kegiatan PKM, cara pembuatan proposal PKM dan pengenalan mitra PCM Kramat Jati dan PWPM DKI Jakarta untuk kegiatan PKM

Dokumentasi :
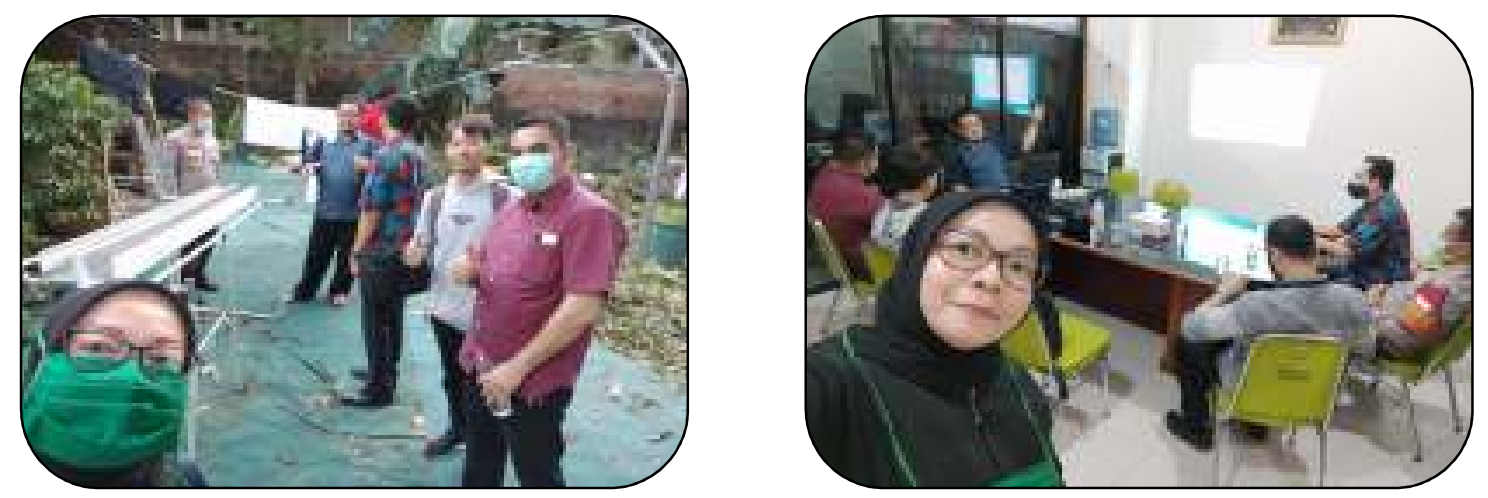

Kegiatan Kedua / Senin, 16 November 2020

\section{Bimbingan PKM}

(Ketua PKM Dr. Marjan Miharja, S.H.,M.H./ Apt. Guntur S.R, S.,Si.)

Pengarahan tentang kemitraan dan produk yang dihasilkan, menjelaskan tentang luaran wajib yang akan dihasilkan.

Dokumentasi :

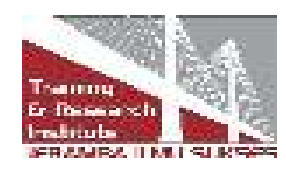



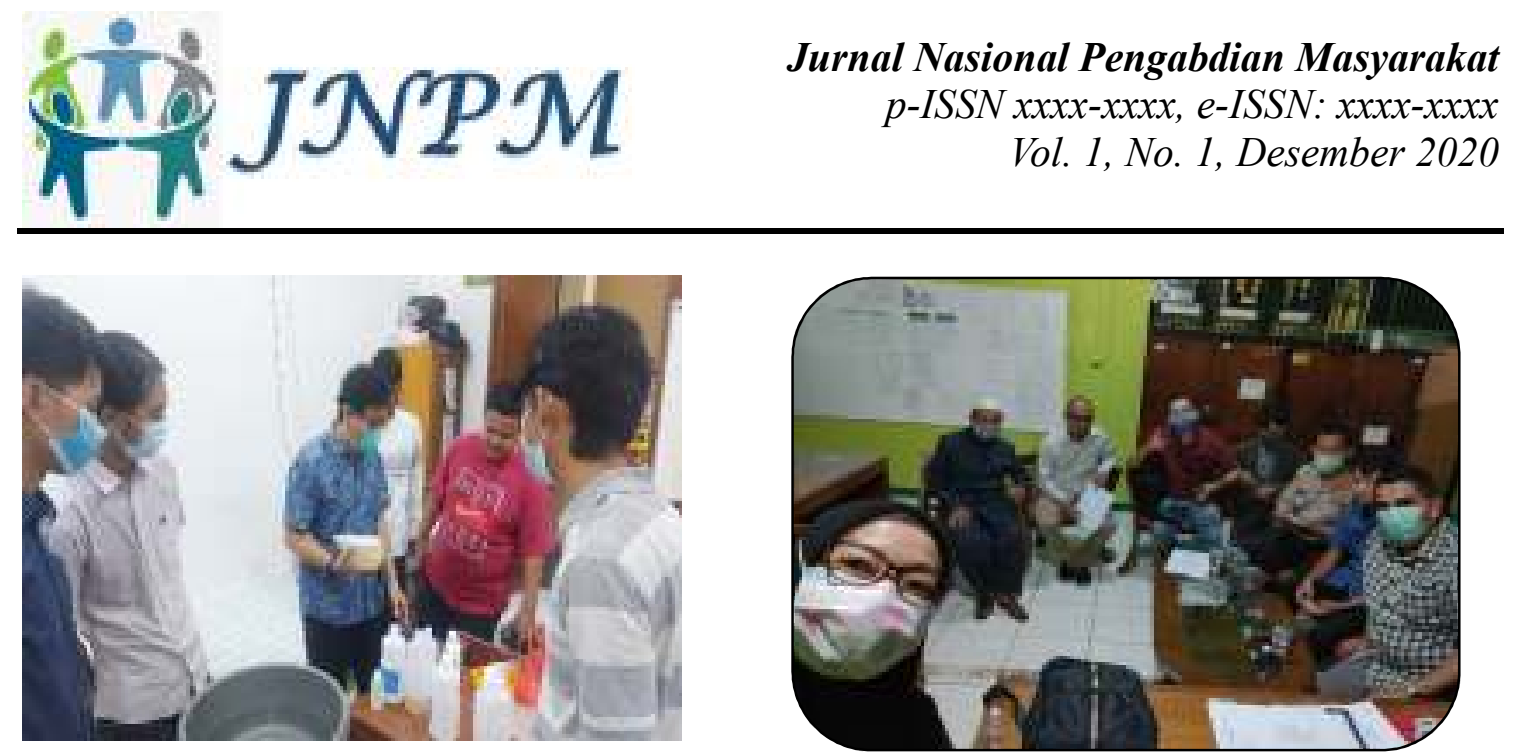

$>\quad$ Kegiatan Ketiga

Bimbingan PKM / Senin, 23 November 2020

(Ketua PKM Dr. Marjan Miharja, S.H.,M.H./ PWPM DKI Jakarta Apt. Guntur S.R , S.,Si.)

Pengarahan tentang tahapan pembuatan Sabun cuci tangan yang aman dan sesuai standar BPOM serta penjelasan tentang komposisi produk.

Dokumentasi :

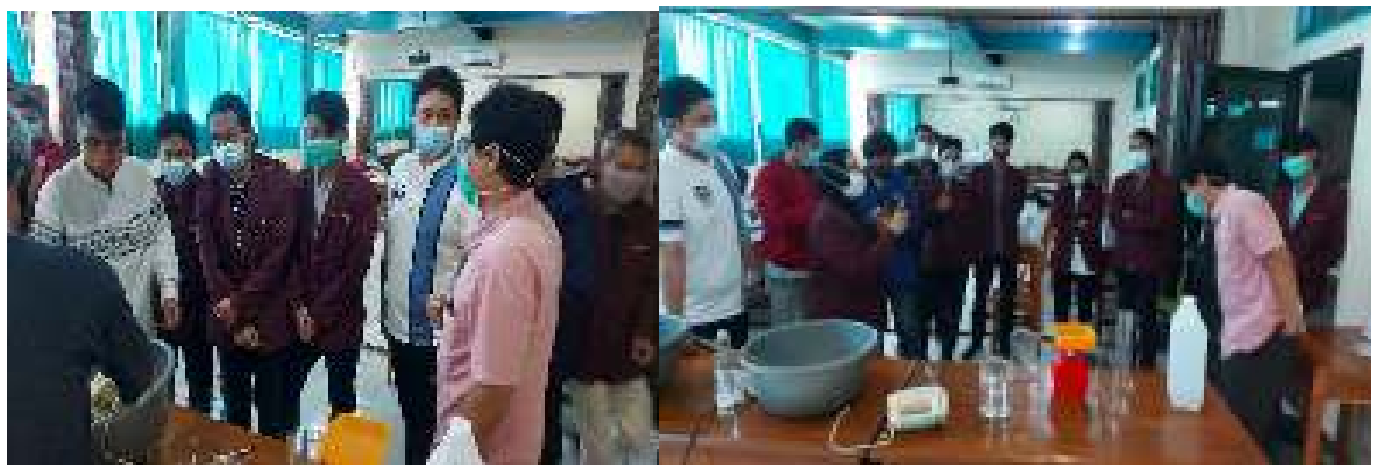

$>\quad$ Kegiatan keempat / Selasa, 24 November 2020

Pengajuan Proposal PKM / Bertempat di STIH IBLAM dan diuji oleh dosen dan Ketua PKM STIH IBLAM

$>\quad$ Kegiatan Kelima / Kamis, 26 November 2020

Bimbingan Pembuatan Produk PKM

(Ketua PWPM DKI Jakarta Apt. Guntur S.R, S.,Si.)

Pembuatan produk sabun cuci tangan sebanyak 100 botol yang terdiri $300 \mathrm{ml} /$ botol, yang akan dipandu oleh mitra PWPM DKI Jakarta.

Dokumentasi :

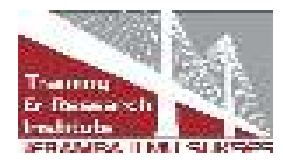



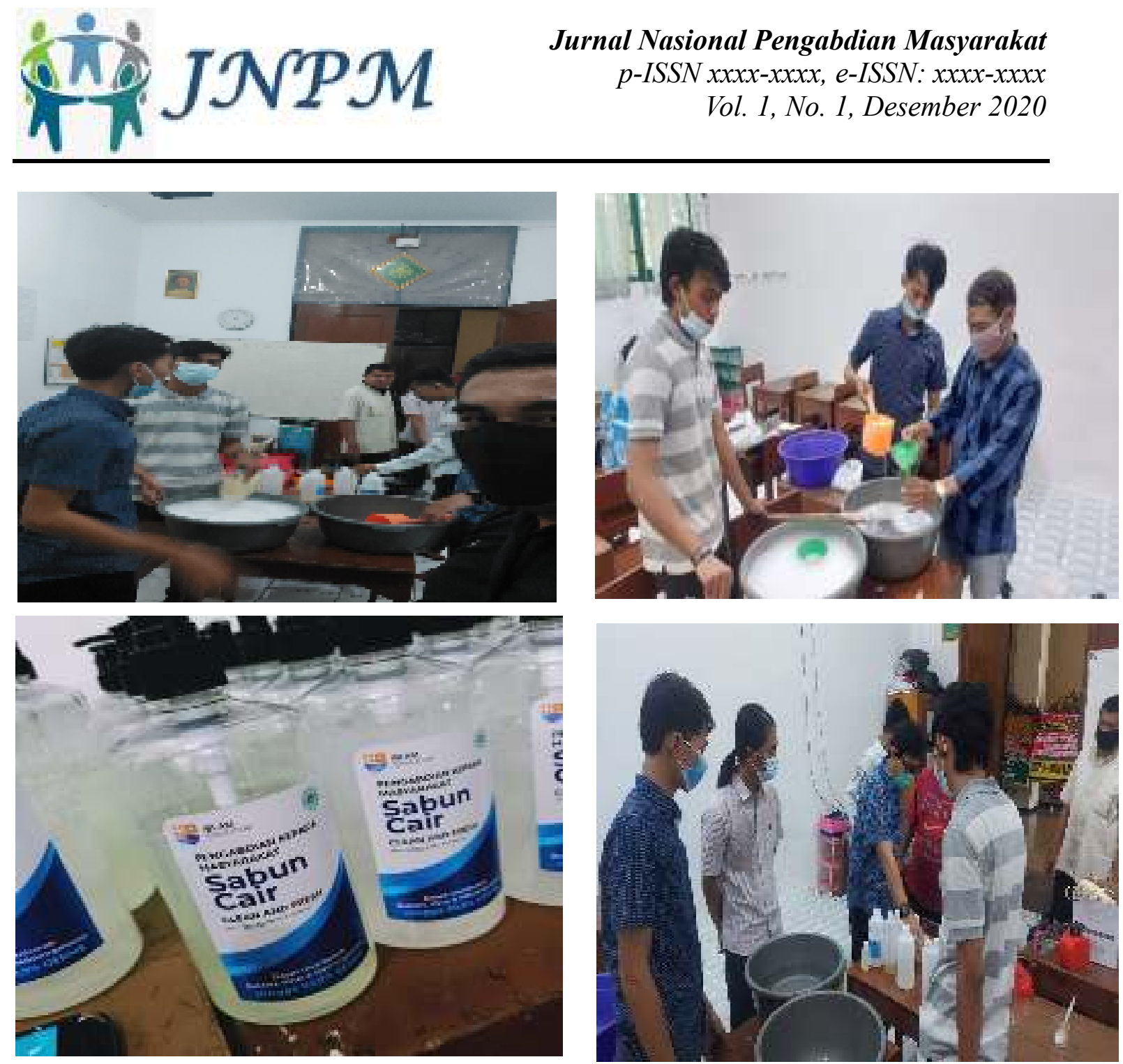

$>\quad$ Kegiatan Keenam

\section{Laporan Harian kegiatan PKM}

Laporan Harian kegiatan PKM ini akan kami buat dalam bentuk jurnal dan kami laporkan kepada Ketua PKM STIH IBLAM

\section{$>\quad$ Kegiatan Ketujuh}

\section{Seminar Laporan Akhir kegiatan PKM}

Kami akan memaparkan laporan kegiatan selama PKM di acara seminar yang akan diselenggarakan ditempat mitra kami yaitu PCM Kramat Jati, Jakarta Timur, DKI Jakarta.

\section{Kesimpulan}

Membuat Produk Handsitizer yang aman dan ramah lingkungan itu tidak sesulit yang dibayangkan, jika kita tahu dan paham kandungan serta aturan yang tepat maka kita dapat membuatnya sendiri dengan aman, hanya yang menjadi masalah disini adalah mendapatkan bahan bahan baku yang kadarnya sesuai dengan yang diinginkan, sehubungan dengan kepakaran mitra kami sehingga link pembelian bahan baku yang dimkasud bukan lagi menjadi masalah dan produk hand sanitizer dapat kami hasilkan.

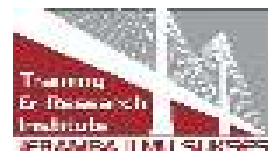




\section{Referensi}

Makhroji, Hasby, Nursamsu. (2020). Pelatihan pembuatan sabun cuci tangan cair untuk pencegahan penularan Covid-19 di desa matang teupah. Jurnal Pengabdian Masyarakat Matang Teupah, 2581-1320.(ejurnal.ikippgribojonegoro.ac.id)

Nur Rohim Yunus, Annissa Rezki, (2020). Lebijakan pemberlakuan lockdown sebagai antisipasi penyebaran corona virus Covid 19., 2356 - 1459, 2654 - 9050. (journal.uinjkt.ac.id).

Peraturan Menteri Kesehatan Nomor 62 tahun 2017 tentang "Izin Edar Alat Kesehatan, Alat Kesehatan Diagnostik In Vitro dan Perbekalan Kesehatan Rumah Tangga”.

Perubahan Kedua Undang-Undang Dasar 1945 kesehatan ditegaskan sebagai bagian dari hak asasi manusia. DalamPasal $28 \mathrm{H}$ ayat (1) dinyatakan, bahwa: "Setiap orang berhak hidup sejahtera lahir dan batin, bertempat tinggal, dan mendapat lingkungan hidup yang baik dan sehat serta berhak memperoleh pelayanan kesehatan."

Undang-undang Nomor 36 Tahun 2014 Tentang Tenaga Kesehatan namun saat ini belum ada peraturan pelaksanaan dan petunjuk teknis Undang-undang Tenaga kesehatan dan undang-undang lainnya yang mengatur tentang perlindungan hukum dan keselamatan kerja bagi Tenaga kesehatan.

Undang-Undang Nomor 6 Tahun 2018 Tentang Kekarantinaan Kesehatan merupakan wewenang absolut Pemerintah Pusat.

Peraturan Pemerintah No. 21 Tahun 2020 Tentang Pembatasan Sosial Berskala Besar dalam rangka Percepatan Penanganan Corona Virus Disease (COVID-19).

\section{Copyrights}

Copyright for this article is retained by the author(s), with first publication rights granted to the journal.

This is an open-access article distributed under the terms and conditions of the Creative Commons Attribution license (http://creativecommons.org/licenses/by/4.0/) 